\title{
Shareholder Protection in China from a Numerical Comparative Law Perspective
}

\author{
Horace Yeung (University of Leicester, United Kingdom; corresponding author: \\ horace.yeung@le.ac.uk)
}

Flora Huang (University of Essex, United Kingdom)

\begin{abstract}
The traditional approach in legal comparative research is doctrinal rule-based. A relatively recent breakthrough has been the use of econometric techniques in comparing the extent of success in different jurisdictions with respect to, for example, protecting shareholders. The meshing of legal research and econometrics is known as 'leximetrics' (Lele \& Siems, 2007). One of the most prominent and widely cited use of leximetrics is the seminal study by La Porta and colleagues $(1997,1998$ \& 2000) on the correlation between shareholder protection and financial development. The study, though highly influential, has attracted various criticisms. Subsequent studies have sought to build on the study by coming up with improved research design. For example, using a panel dataset covering a range of developed and developing countries, researchers from the Cambridge Centre for Business Research have discovered that a significant upward movement in the level of shareholder protection was made by China between 1990 and 2013 (Armour et al., 2009; Siems, 2016). It has been suggested that between the period, China experienced the 'biggest increase in shareholder protection' amongst 30 countries studied, and China was amongst the top performers (along with France and Russia) in shareholder protection in 2013, performing even better than the UK and the US. At the same time, the World Bank's (2017) Protecting Minority Investors Index, which forms part of its Doing Business Reports, has recently painted a rather opposite picture, in contrast to the positive assessment by the Centre for Business Research, by putting China in the 119th position out of 190 countries which indicates a very mediocre performance. This article seeks to address the question of whether and how the two studies, both employing leximetric techniques and examining an ostensibly similar issue, can point to discrepant results.
\end{abstract}

* This article was originally prepared for the Inaugural Conference of the Chinese Journal of Comparative Law on 'Comparative Law: The Past, Present and Future' on 9-10 June 2018, at Xi'an Jiaotong University, Xi'an, China. The authors would like to thank Prof. Lutz-Christian Wolff and two anonymous reviewers for their detailed comments. All errors are our own. 


\section{Introduction}

The role of institutions has become one of the most popular research areas as a result of the rise of New Institutional Economics in the 1980s. ${ }^{1}$ The study of institutions is important as it provides an explanation of international differences in economic development, which in turn can inform policy reform proposals both for international organisations like the World Bank and the OECD, as well as the governments of different countries. Different types of institutions have been examined by scholars in an abundant amount of studies with a view to providing a plausible explanation of cross-country differences in economic growth.

As a ground-breaking contribution to Institutional Economics, La Porta and colleagues have examined legal rules covering the protection of corporate shareholders and creditors, the origin of these rules and the quality of their enforcement in 49 countries. ${ }^{2}$ The study by La Porta and colleagues has phenomenally started a new branch of legal scholarship known as 'Law and Finance', which seeks to unearth the correlation between law and financial development. ${ }^{3}$

Allen and colleagues once famously put the law, finance and growth nexus in the context of China. ${ }^{4}$ They argued that China represented an important counter-example to the wider law, institutions, finance, and growth literatures: neither the legal nor financial system was well developed, yet it had one of the fastest growing economies. However, this view inevitably has to be adjusted after more than a decade of development. Nowadays, it is worth noting that the Shanghai Stock Exchange is the fourth largest stock exchange in the world. ${ }^{5}$ Also, according to the Cambridge Centre for Business Research, China was one of the top performers in shareholder protection in 2013 amongst 30 jurisdictions studied, performing even better than the UK and the US. ${ }^{6}$ All these newer observations point to a confirmation of the law-financegrowth nexus. China has strong laws, strong financial markets and strong economic growth. In

\footnotetext{
${ }^{1}$ Ha-Joon Chang, 'Institutions and Economic Development: Theory, Policy and History' (2011) 7 Journal of Institutional Economics 473.

${ }^{2}$ See Rafael La Porta et al, 'Legal Determinants of External Finance' (1997) 52 Journal of Finance 1131; La Porta et al, 'Law and Finance' (1998) 106 Journal of Political Economy 1113; La Porta et al, 'Investor Protection and Corporate Governance' (2000) 58 Journal of Financial Economics 3.

${ }^{3}$ Mathias Siems, 'Legal Origins: Reconciling Law \& Finance and Comparative Law' (2007) 52 McGill Law Journal 55, 57.

${ }^{4}$ Franklin Allen et al, 'Law, Finance, and Economic Growth in China' (2005) 77 Journal of Financial Economics 57.

${ }^{5}$ The top 5 are: New York Stock Exchange, NASDAQ, Tokyo Stock Exchange, Shanghai Stock Exchange and London Stock Exchange, according to market capitalisation. Data from the World Federation of Exchanges, as of June 2017.

${ }^{6}$ Dionysia Katelouzou and Mathias Siems, 'Disappearing Paradigms in Shareholder Protection: Leximetric Evidence for 30 Countries, 1990-2013’ (2015) 15 Journal of Corporate Law Studies 127, 134.
} 
a sharp contrast, the World Bank's Protecting Minority Investors Index, which forms part of its Doing Business Reports, presents a more pessimistic assessment by putting China in the 119th position out of 190 countries. ${ }^{7}$ China's score of 4.8 was below the East Asia and Pacific average of 5.2, and below the average for OECD high income countries of 6.4. This article seeks to address this discrepant result, where China is both strong and mediocre in shareholder protection according to the two studies, which are largely built on the leximetric technique introduced by La Porta and colleagues.

The first part of this paper will discuss the concerns arising from comparative law research, especially in a numerical context. The second part will discuss the trajectory of corporate and financial law reforms in China to establish a prima facie case of whether or not China is really a 'top performer' in protecting shareholders. Afterwards, the paper will compare and contrast in detail the methodological approaches and results of the two studies by the Cambridge Centre for Business Research and the World Bank respectively to unearth the root of discrepancies. Finally, the article will summarise some key observations made in this article and briefly reflect on their implications in the conclusion.

\section{A. Numerical Comparative Law}

Comparative law as a methodology has become particularly relevant as a result of globalisation, because the process of globalisation is fundamentally changing the significance of national and societal boundaries and generally making them less important. ${ }^{8}$ This situation requires an effective method to compare and contrast norms, institutions, cultures, attitudes, methodologies, even entire legal systems, ${ }^{9}$ and resolve problems arising from trans-border transactions and events. ${ }^{10}$ There is a spectrum of methods and the best approach will always be adapted in terms of the specific purposes of the research.

The traditional approach in legal research is rule-based comparison. One approach is what Zweigert postulated as functionalism, which looks at the common function served by legal

\footnotetext{
7 The World Bank, 'Doing Business - China' (2017)

<http://www.doingbusiness.org/data/exploreeconomies/china/\#protecting-minority-investors $>$.

${ }^{8}$ William Twining, Globalisation and Legal Theory (CUP, 2000) 81.

${ }^{9}$ Vernon Valentime Palmer, 'From Lerotholi to Lando: Some Examples of Comparative Law Methodology' (2005) 53 American Journal of Comparative Law 261, 262.

${ }^{10}$ Nicholas Foster, 'The Journal of Comparative Law: A New Scholarly Resource' (2006) 1 Journal of Comparative Law 1, 8.
} 
systems. ${ }^{11}$ Other methods include legal history, numerical comparison, economics, and crosscultural psychology. Watson argued that, in the first instance, comparative law was concerned with legal history. ${ }^{12}$ Often, comparison is seen as the social science's equivalent of experiments, as a test for general theories of human behaviour. ${ }^{13}$ Thus, comparative economics and cross-cultural psychology can be applied to different nations. Meanwhile, numerical comparison is used by some scholars in an attempt to answer a complex question with a mere number. ${ }^{14}$

Each method has its arguments for and against. For instance, rule-based comparison seems like the most obvious thing to do. But it fails to take account of systemic differences. For example, how can one compare English and French trusts? This is impossible since trusts do not exist in French law. One perceived solution is functionality which is regarded by many as the basic methodological principle of all comparative law. ${ }^{15}$ Instead of asking: 'What legal requirements are there for sales contracts in foreign law?' it is better to inquire, 'How does foreign law protect parties from surprise, of from being held to an agreement not seriously intended?' ${ }^{16}$ However, the drawbacks of functionality are how to define 'function' and whether function is identical in legal systems. ${ }^{17}$ In addition, it does not consider cultural and historical differences. ${ }^{18}$ Van Hoecke and Warrington observed that the need for a broad approach to the subject of comparative law, thereby moving it beyond the 'law as rules' approach of traditional legal doctrine, had been acknowledged for some time. ${ }^{19}$ It is becoming steadily apparent that comparatists cannot limit themselves to simply comparing rules. The 'law as rules' approach has to be placed in a much wider context. The 'context of law' is an essential part of

\footnotetext{
${ }^{11}$ For a comprehensive picture of functionality, see Konrad Zweigert, 'Methodological Problems in Comparative Law' (1972) 7 Israel Law Review 465.

12 Alan Watson, Legal Transplants an Approach to Comparative Law (University of Georgia Press, 1993) 6; see also Konrad Zweigert and Hein Kötz, An Introduction to Comparative Law (OUP, 1998) 8-10.

${ }^{13}$ Niles Jansen, 'Comparative Law and Comparative Knowledge' in Mathias Reimann and Reinhard Zimmermann (eds), The Oxford Handbook of Comparative Law, (OUP, 2006) 319-320.

${ }^{14}$ For example, La Porta el al distinguished several legal measures that are decisive for the protection of shareholder. Subsequently, they looked at those indicators in 49 countries, and accordingly marked each country '0' or ' 1 '. See La Porta el al (n 2).

15 For example, Zweigert and Kötz (n 12) 34; and John Reitz, 'How to Do Comparative Law' (1998) 46 American Journal of Comparative Law 617, 620-623.

${ }^{16}$ Zweigert (n 11) 467.

${ }^{17}$ According to Zweigert and Kötz, 'in law the only things which are comparable are those which fulfil the same function'. See Zweigert and Kötz (n 12) 34.

${ }^{18}$ For arguments against functionality, see Ralf Michaels, 'The Functional Method of Comparative Law' in Mathias Reimann and Reinhard Zimmermann (eds), The Oxford Handbook of Comparative Law (OUP, 2006) 381.

${ }^{19}$ Mark Van Hoecke and Mark Warrington, 'Legal Cultures, Legal Paradigms and Legal Doctrine: Towards a New Model for Comparative Law' (1998) 47 International and Comparative Law Quarterly 495.
} 
comparative research. ${ }^{20}$ This context is not only the material context of sociology, history, economy, but also the ideological context of the law and 'law as culture'. Therefore, comparison entails a societal comparison of the actual role and functioning of law in the compared societies, rather than comparing statutory rules or court decisions.

According to Lele and Siems, there has been an increasing trend to quantify the law in relation to shareholder protection following on the influential study by La Porta and colleagues. ${ }^{21}$ The use of a 'leximetric' approach opens up into the study of comparative shareholder protection law. ${ }^{22}$ According to Cooter and Ginsburg, leximetrics may be able to allow comparative scholars to specify the relationship between law and finance with greater precision. ${ }^{23}$ The idea of a 'legalisation' index variable could facilitate comparative assessment of legal systems. Furthermore, it may also help establish how specificity in a single jurisdiction changes over time in response to various causal factors. ${ }^{24}$

La Porta and colleagues have examined legal rules covering the protection of corporate shareholders and creditors, the origin of these rules and the quality of their enforcement in 49 countries. ${ }^{25}$ In this study, they used six variables to construct an index for 'anti-director rights'. La Porta and colleagues have demonstrated a positive correlation between levels of investor protection and the development of capital markets. Two core ideas evolve from their law and finance theory. The first idea concerns 'legal family': shareholder laws in common law countries are superior to those in civil law countries. The second idea is that 'law matters': legal doctrine is crucial to financial market development (while enforcement has been overlooked). One may argue whether there is a causality or a reversed relationship between market development and legal rules. In contrast to La Porte and others' approach, Coffee and Cheffins have shown, in the UK and the US the opposite sequence that financial markets develop first, and then create a political demand for investor protection. ${ }^{26}$ This shows that

\footnotetext{
${ }^{20}$ Ibid. 532.

${ }^{21}$ Priya Lele and Mathias Siems, 'Shareholder Protection: A Leximetric Approach' (2007) 7 Journal of Corporate Law Studies 17.

${ }^{22}$ According to Lele and Siems, this term was first used in Robert Cooter and Tim Ginsburg, 'Leximetrics: Why the Same Laws are Longer in Some Countries than Others' (2003), available at: $<$ http://ssrn.com/abstract=456520>.

23 Ibid.

24 Ibid.

${ }^{25}$ See La Porta et al (n 2).

${ }^{26}$ See John Coffee, 'The Rise of Dispersed Ownership: The Role of Law and the State in the Separation of Ownership and Control' (2001) 111 Yale Law Journal 1, 65-66; and Brian Cheffins, 'Does Law Matter? The Separation of Ownership and Control in the United Kingdom' (2001) 30 Journal of Legal Studies 459, 483-484.
} 
despite empirical evidence may point to the observation that strong laws and markets co-exist, it is not clear if one is the cause of another.

In Siems's view, the comparative law methodology adopted by La Porta and colleagues is problematic because particular rules are not identical in different countries. ${ }^{27}$ Furthermore, it is doubtful whether the division between common and civil law is useful in talking about comparative corporate law. A strict division between legal families does not fit since international trade and legal transplants have always existed in this field. ${ }^{28}$ Such classification using legal families, with little regard to each particular country's 'demand for law' in the first place, later attracted criticisms from other scholars. ${ }^{29}$ As suggested by Siems, it is overlysimplistic to examine how different legal families shape finance. ${ }^{30}$ Roe rightly indicates that the distinction between common law and civil law systems is often exaggerated. ${ }^{31}$ Modern securities regulation revolves around a regulatory agency operating through a comprehensive regulatory code. This is not an intrinsic common law institutional advantage. The idea of the dominance of legal rules in financial markets is also in question. Coffee, Jackson and Roe, as well as Armour and colleagues have shown that enforcement is as important as substantive law for a strong capital market. ${ }^{32}$

Furthermore, a country's legal origin is not exogenous and thus has a political, social, economic, and cultural context. While La Porta and colleagues have pointed out the importance of legal foundation in terms of shareholder protection to capital market development, Roe has indicated that the political economy-based theories seem stronger than the legal origins theory. ${ }^{33} \mathrm{He}$ argues that continental social democracies did not provide institutions that securities markets need, such that the markets in continental Europe have flourished to a lesser degree than their Anglo-American counterparts. In social democracies, employees are

\footnotetext{
${ }^{27}$ For a summary, see Mathias Siems, 'What Does Not Work in Comparing Securities Laws: A Critique on La Porta et al's Methodology' (2005) 16 International Company and Commercial Law Review 300.

${ }^{28}$ Mathias Siems, 'Numerical Comparative Law - Do We Need Statistical Evidence in Law in Order to Reduce Complexity?' (2005) 13 Cardozo Journal of International \& Comparative Law 521, 528.

${ }^{29}$ See for example, Daniel Berkowit et al, 'Economic Development, Legality and the Transplant Effect' (2003) 47 European Economic Review 165 and Siems (n 3). A mere categorisation of a system as common law or civil law disregards deeper legal structures.

${ }^{30}$ Siems (n 3) 15.

${ }^{31}$ Mark Roe, 'Legal Origins, Politics and Modern Stock Markets' (2006) 120 Harvard Law Review 460, 481.

32 John Coffee, 'Law and Market: the Impact of Enforcement' (2007) 156 University of Pennsylvania Law Review 229; Howell Jackson and Mark Roe, 'Public and Private Enforcement of Securities Laws: ResourceBased Evidence' (2009) 93 Journal of Financial Economics 207; and John Armour et al, 'Private Enforcement of Corporate Law: An Empirical Comparison of the US and UK' (2009) 6 Journal of Empirical Legal Studies 687.

${ }^{33}$ Mark Roe, Political Determinant of Corporate Governance (OUP, 2003).
} 
protected from actions that a company would often take to maximise the shareholder's value. The goals between employees and shareholders often do not intersect. Employees prefer high wages and shareholders prefer lower wages. There is even an investment horizon problem. Employees are risk-averse because unlike a shareholder, who can have a diversified investment portfolio, their human capital is tied up in the company. Therefore, Roe's argument is that 'where labour's influence is strong, concentrated ownership should persist as a countervailing power and, hence, equity markets should develop less strongly' and he supports his argument by showing the correlation between political orientation and ownership structure. ${ }^{34}$ Furthermore, political forces can also have direct influence. For example, in the continental system, those in power want to exercise more control through a bank-centred system because large banks are subject to more state control than securities markets. ${ }^{35}$ This is clearly another political explanation of weak financial markets. Also, culture can be important. According to Licht and colleagues, particular cultural profiles in some regions are less compatible with good governance than with the profiles of West European and English-speaking countries. ${ }^{36}$ This perhaps can explain why the capital markets in some countries are weaker and also indicate the challenges faced by some emerging economies. Meanwhile, Siems has highlighted that the combination of legal and non-legal considerations can be problematic. ${ }^{37}$ It is difficult to know whether and how to aggregate these considerations.

Another critique on La Porta's methodology is their use of a limited set of criteria for their study on shareholder protection. ${ }^{38}$ It is doubtful whether six variables are good proxies for the general level of shareholder protection since they do not capture many important aspects of company law. While statistical analysis is widely utilised in the field of social science with a view to reducing complexity, giving legal rules 'ones' and 'zeros' may reduce the 'richness of detail' in legal research. ${ }^{39}$ In fact, as indicated by Spamann, many of the initial results from La

\footnotetext{
${ }^{34}$ Roe (n 31) 503.

${ }^{35}$ Coffee (n 26) 75. Power seeking nationalists use banks as their agents and these banks resist the rise of rivals, the securities markets, for their business.

${ }^{36}$ Amir Licht et al, 'Culture Rules: The Foundations of the Rule of Law and Other Norms of Governance' (2007) 35 Journal of Comparative Economics 659. A study was conducted based on a comparison between a taxonomy of corporate governance regimes according to legal families and a classification of countries according to their shared cultural values.

${ }^{37}$ Mathias Siems, Comparative Law (CUP, 2014) 173.

${ }^{38}$ Ibid. 170; Lele and Siems (n 21) 19-21.

${ }^{39}$ Kenneth Dam, The Law-Growth Nexus (Brookings, 2006) 171.
} 
Porta and colleagues are not robust to the correction of coding errors. ${ }^{40}$ Legal rules differ across many relevant dimensions, in particular in international comparison. It is simply very difficult to draw the lines in each of them by variable definitions.

Although the cross-country leximetric tests may have flaws, they have raised the awareness of the role of legal institutions for the performance of capital markets. The close link between investor protection and stock market development is widely accepted by policymakers and scholars. The next step will be to understand how the legal system actually helps. In a qualitative way, the focus will be put on how minority shareholders are protected from predatory controlling shareholders and opportunistic managers when studying the role of law and legal institutions in the context of corporation and equity finance in China.

\section{B. Trajectory of Development in Chinese Corporate and Financial Law}

In December 1978, the Third Plenary Session of the $11^{\text {th }}$ Central Committee of the Communist Party of China marked a new historic period of gaige kaifang, the twin strategies of economic reform and opening up. Prior to that, arguably there had not been a great demand for corporate and financial law, which is largely a branch of private law, in a predominantly state-dominated economy. One goal of company law should be to enable the organisation of economic activities in the private sector. In relation to SOE reform, the proposal to reform in China has had three broad phases: the state's withdrawal from the operational decisions of SOEs, then from administrative oversight and ultimately from ownership. This was clearly reflected from the decline in the relative share of the exclusively state-owned companies in the economy and the emergence of hybrid structures co-owned by state entities and non-state actors. ${ }^{41}$

\footnotetext{
${ }^{40}$ Holger Spamann, 'The “Antidirector Rights Index” Revisited' (2010) 23 Review of Financial Studies 467.

${ }^{41}$ Statistically, the dominance of SOEs in the Chinese economy has been diminishing from accounting for 76 per cent of annual gross industrial output in 1980 to only around 15 percent in 2006 . However, in some public utility industries including water, electricity, thermal energy and fuel, the market share of SOEs still exceeds 50
} 
In response to the economic reforms, various laws were introduced as the supporting institutions. ${ }^{42}$ According to Lubman, it was important as the market economy relies on private law to serve as a framework to facilitate transactions defining the rights and duties created by business arrangements. ${ }^{43}$ For example, two laws related to foreign investment, the Law on Wholly Foreign-owned Enterprises and the Law on Sino-foreign Cooperative Joint Venture Enterprises, were promulgated in 1986 and 1988 respectively. For the SOE reform, the Law on Industrial Enterprises Owned by the Whole People, an early draft of the Company Law 1993, reaffirmed that the Communist Party's explicit desire that the ownership and management of SOEs 'be appropriately separated' ${ }^{44}$ The regulatory response to the emergence of domestic enterprises came in 1992. The Standard Opinion for Limited Liability Companies and the Standard Opinion for Companies Limited by Shares were issued as interim measures before the promulgation of a comprehensive set of company laws. The first Company Law, based on previous draft regulations and the two Standard Opinions, was passed on 29 December 1993 and became effective on 1 July 1994.

The law served two main functions: first to establish a modern enterprise system compatible with the social market economy, and second to set out the legal basis for regulating different types of companies. The Company Law has since been amended four times, in 1999 and 2004 to a limited extent, with more radical changes introduced in 2005 and $2013 .{ }^{45}$ The early

\footnotetext{
percent in order to protect public interests. See Sanlin Jin and Yuanyuan Wei, 'Extent of Government Ownership or Control of the Means of Production and Enterprises' in Xiaoxi Li (ed.), Assessing the Extent of China's Marketisation (Ashgate, 2006) 239-242.

${ }^{42}$ Previous attempt to put the law-growth nexus into the context of China includes: Franklin Allen et al, 'Law, Finance, and Economic Growth in China' (2005) 77 Journal of Financial Economics 57; Dam (n 39) 232-78; Horace Yeung and Flora Huang, 'Growth without Institutions? The Case of China' (2013) 3 Durham Law Review 327; and Ding Chen and Simon Deakin, 'On Heaven's Lathe: State, Rule of Law, and Economic Development' (2015) 8 Law and Development Review 123.

${ }^{43}$ Stanley Lubman, Bird in a Cage: Legal Reform in China after Mao (Stanford University Press, 1999) 174.

${ }^{44}$ The law was enacted by the National People's Congress in 1988.

${ }^{45}$ The 2005 amendments enhanced shareholder rights in a number of aspects. See Flora Huang, 'Modernising
} 
Company Law was designed to pursue a distinctive mission in the socialist state of China, which was, to build an economic system that maintains socialist principles and goals. ${ }^{46}$ In a sharp contrast, the Company Law 2005 clearly stated that its aims are to 'protect the legitimate and interests of companies, shareholders and creditors' and, at the same time, 'to promote the development of the socialist market economy.${ }^{47}$ Until the Company Law came into effect on 1 July 1994, China had been unique in having shareholding companies and a securities market operating without either company law or securities law. ${ }^{48}$ Although the early legal framework was heavily criticised, it is believed that the current framework (laws-on-the-books) nowadays is comparable to developed countries, despite the doubt of whether other relevant supporting institutions are adequate. ${ }^{49}$

The most notable improvement in shareholder protection was provided by the Company Law 2005, and the current Company Law 2013 is generally following its predecessor. For a summary of key changes, see the Table 1 below.

\footnotetext{
the Chinese Capital Market: Old Problems and New Legal Responses' (2010) 21 International Company and Commercial Law Review 26. The recent company law amendments in 2013 removed the requirement for companies to have a minimum level of capitalisation. It is expected to encourage more entrepreneurs to start their own businesses fostering the growth of the individual economic sector. See PwC China, 'China's Amended Company Law Facilitating More Business' (2014). Available at <https://www.pwccn.com/en/china-taxnews/chinatax-news-jan2014-1.pdf>.

${ }^{46}$ See Robert Art, and Minkang Gu, 'China Incorporated: The First Corporation Law of the People's Republic of China' (1995) 20 Yale Journal of International Law 274.

${ }^{47}$ See art 1 of the Company Law 2005.

${ }^{48}$ Until the first set of securities laws came into effect in 1999, the Company Law had been supplemented by the Interim Regulations on Share Issuing and Trading, issued in May 1993 by the State Council Securities Committee, to help regulate the stock market. The Chinese Securities Law was adopted by the Standing Committee of the National People's Congress on 29 December 1998, effective as of 1 July 1999, amended on 28 August 2004 and revised 27 October 2005, effective as of 1 January 2006. The law was amended for the second time in 2013 and third time in 2014. The current version is the Securities Law 2014.

${ }^{49}$ For example, Lubman criticised that Chinese legal reform tended to use numerous general terms to express vague legal standards. See Lubman (n 43) 186. As briefly mentioned in the beginning, China is now amongst the top performers of shareholder protection, see Katelouzou and Siems (n 6). But laws-in-action can remain an issue. For example, Yeung expressed his concerns over the quality of Chinese judges and legal profession. See Horace Yeung, 'Transferability of English Legal Concepts and Skills in China with respect to Corporate Regulation' in Georges Depeyrot (ed.), When Orient and Occident Meet (Moneta, 2014) 347-348.
} 
Table 1 - Selected Features of the Three Laws

\begin{tabular}{|c|c|c|c|}
\hline Description & $\begin{array}{c}\text { Company Law } \\
1993\end{array}$ & $\begin{array}{c}\text { Company Law } \\
2005\end{array}$ & $\begin{array}{c}\text { Company Law } \\
2013\end{array}$ \\
\hline $\begin{array}{l}\text { Fiduciary Duty of } \\
\text { Directors, } \\
\text { Supervisors and } \\
\text { Senior Personnel }\end{array}$ & $\begin{array}{l}\text { Duty of loyalty only } \\
\text { (art. 59) }\end{array}$ & $\begin{array}{l}\text { Duties of loyalty and } \\
\text { care (art. 148) }\end{array}$ & $\begin{array}{l}\text { Same as Company } \\
\text { Law } 2005 \text { (art. 147) }\end{array}$ \\
\hline $\begin{array}{l}\text { Fiduciary Duty of } \\
\text { Controlling } \\
\text { Shareholders }\end{array}$ & N/A & $\begin{array}{l}\text { Controlling } \\
\text { shareholders ( } 50 \% \text { or } \\
\text { up) must show good } \\
\text { faith in exercising } \\
\text { their rights (art. } 21)\end{array}$ & $\begin{array}{l}\text { Same as Company } \\
\text { Law } 2005 \text { (art. 21) }\end{array}$ \\
\hline Exit Strategy & N/A & $\begin{array}{l}\text { 1. Fail to distribute } \\
\text { profits; } \\
\text { 2. Merger or split of } \\
\text { company; } \\
\text { 3. Renewal of } \\
\text { operation term or } \\
\text { dissolution } \\
\text { (art. 75) }\end{array}$ & $\begin{array}{l}\text { Same as Company } \\
\text { Law } 2005 \text { (art. 74) }\end{array}$ \\
\hline Information Rights & $\begin{array}{l}\text { Basic passive } \\
\text { information rights } \\
\text { (arts. 32 \& 110) }\end{array}$ & $\begin{array}{l}\text { Enhanced } \\
\text { information right } \\
\text { plus right of making } \\
\text { inquiries (arts. } 34 \& \\
\text { 151) }\end{array}$ & $\begin{array}{l}\text { Same as Company } \\
\text { Law } 2005 \text { (arts. } 33 \& \\
150)\end{array}$ \\
\hline $\begin{array}{l}\text { Shareholders' } \\
\text { Meetings }\end{array}$ & $\begin{array}{l}\text { Basic powers (art. } \\
103 \text { ) }\end{array}$ & $\begin{array}{l}\text { 1. Power to initiate } \\
\text { new motion ( } 3 \% \text { of } \\
\text { shareholding); } \\
\text { 2. Right to individual } \\
\text { notice (art. 103) }\end{array}$ & $\begin{array}{l}\text { Same as Company } \\
\text { Law } 2005 \text { (art. 102) }\end{array}$ \\
\hline $\begin{array}{l}\text { Private Placement } \\
\text { of Shares }\end{array}$ & Not allowed (art. 73) & Allowed (art. 78) & $\begin{array}{l}\text { Same as Company } \\
\text { Law } 2005 \text { (art. 77) }\end{array}$ \\
\hline Pre-emptive Right & N/A & Yes (art. 35) & $\begin{array}{l}\text { Same as Company } \\
\text { Law } 2005 \text { (art. 34) }\end{array}$ \\
\hline Shareholder Action & $\begin{array}{l}\text { No mention of civil } \\
\text { remedies }\end{array}$ & $\begin{array}{l}\text { Derivative actions } \\
\text { permitted and in } \\
\text { some cases direct } \\
\text { actions (arts. } 152 \& \\
153 \text { ) }\end{array}$ & $\begin{array}{l}\text { Same as Company } \\
\text { Law 2005 (arts. 151 } \\
\& 152 \text { ) }\end{array}$ \\
\hline
\end{tabular}

Corporate law seeks to perform two general functions: first to establish the corporate form; and second to control conflicts of interest among corporate constituencies ${ }^{50}$ On the other hand, the

\footnotetext{
50 John Armour et al, 'Agency Problems and Legal Strategies' in John Armour et al (eds), The Anatomy of Corporate Law: A Comparative and Functional Approach (OUP, 2017) 29-30.
} 
securities law and together with other financial market rules, such as the corporate governance code and the listing rules, seek to fulfil two objectives: first to ensure that the prices of publicly traded securities are reasonably well-informed and second to ensure that public shareholders are protected by effective corporate governance arrangements once they become shareholders. ${ }^{51}$ For example, the Chinese securities law requires regular and ad hoc disclosures from listed companies. ${ }^{52}$ Also, it is possible for the market regulator, China Securities Regulatory Commission (CSRC), to bring criminal or administrative actions against companies and their officers who have engaged in market misconduct. ${ }^{53}$ Further, in China, regulatory requirements regarding corporate governance are reflected in the Code of Corporate Governance for Listed Companies issued in January 2002, which was developed in accordance with the OECD Principles of Corporate Governance. The principal difference between the Chinese framework and that of elsewhere like the UK is that a 'comply or explain' principle has not been adopted. A listed company is required to take the contents specified in the Code into account when formulating or revising its articles of association and detailed management rules. ${ }^{54}$ Meanwhile, the CSRC has issued certain rules to implement the provisions in the Code. For instance, according to the Guidelines for Introducing Independent Directors to the Board of Directors of Listed Companies ${ }^{55}$, independent directors are to account for at least one-third of the membership of a company's board of directors and should include at least one professional accountant. Compensation, audit and nomination committees are required to be chaired by an independent director and must be constituted by a majority of independent directors. ${ }^{56}$ All of the discussions above have to a large degree illustrated China's commitment

\footnotetext{
${ }^{51}$ Luca Enriques et al, 'Corporate Law and Securities Markets' in John Armour et al (eds), The Anatomy of Corporate Law: A Comparative and Functional Approach (OUP, 2017) 243-258. See also Louise Gullifer and Jennifer Payne, Corporate Finance Law: Principles and Policy (Hart, 2015) 487.

52 Securities Law 2014, arts 66 \& 67.

${ }^{53}$ See Chapter XI of the Securities Law 2014.

${ }^{54}$ The Preamble of the Chinese Corporate Governance Code.

${ }^{55}$ Zhengjianfa [2001] No. 102, issued on 16 August 2001.

56 The Chinese Corporate Governance Code, art 52.
} 
to continuously improving its regulatory regime.

\section{What Numerical Comparative Law Tells Us about China}

Numerical comparative law has the dual use of measuring similarities and differences between systems, and measuring the quality of legal rules. ${ }^{57}$ From above, it is clear that China has made observable efforts in improving shareholder protection. However, it is still unclear how it has fared against other economies. The question can perhaps be answered by looking at some existing cross-country shareholder protection indices. The obvious one can be that compiled by La Porta and colleagues. ${ }^{58}$ Unfortunately, despite 49 countries were covered by their index, China was not one of them. Indeed, they did not include any socialist or 'transition' economies in the countries studied. Also, La Porta and colleagues examined the legal rules of the countries during 1993-1994. The result would be too outdated considering the first company law in China did not become effective until 1 July 1994.

Despite La Porta and colleagues' initial research was so controversial, later studies were largely built upon it and had improved research design. For example, Djankov and colleagues have looked at a new measure of legal protection of minority shareholders against expropriation by corporate insiders: the anti-self-dealing index, as opposed to the index of anti-director rights adopted by La Porta and colleagues. ${ }^{59}$ The index was compiled for 72 countries and focused on private enforcement mechanisms, such as disclosure, approval, and litigation, governing a specific self-dealing transaction. According to their findings, the index was sharply higher in common law countries than in French civil law countries. Also, the index was believed to be a statistically significant and economically strong predictor of a variety of measures of stock

\footnotetext{
${ }^{57}$ Siems (n 37) 147.

${ }^{58} \mathrm{La}$ Porta et al (n 2).

${ }^{59}$ Simeon Djankov et al, 'The Law and Economics of Self-dealing' (2008) 88 Journal of Financial Economics 430.
} 
market development across countries. These results generally supported the findings of the earlier work by La Porta and colleagues. The Protecting Minority Investors Index in the World Bank's Doing Business project is indeed based on the methodology adopted by Djankov and colleagues. ${ }^{60}$

The importance of legal institutions in fostering a good business environment is underlined by the World Bank's Doing Business project. ${ }^{61}$ This project provides objective measures of business regulations and their enforcement across 190 economies and selected cities at the subnational and regional level. The first Doing Business report, published in 2003, covered 5 indicator sets and 133 economies. The most recent report in 2017 covers 11 indicator sets and 190 economies. Amongst which, the Protecting Minority Investors indicator is perhaps the most relevant in the context of this paper. The indicator measures the extent of protection from conflicts of interest and shareholders' rights in corporate governance. ${ }^{62}$ The higher the index indicates a better protection of investors' interests. The maximum score is 10. OECD high income countries on average get a score of 6.4 in 2017. On the other hand, China is ranked 119th with a rather low score of 4.8 .

However, this does not necessarily indicate a grave concern about the legal institutions in China. If one looks at another dataset, there can be an entirely different conclusion. In light of the panel dataset covering a range of developed and developing countries from Armour and colleagues (for the Cambridge Centre of Business Research), they discovered that a significant upward movement in the level of shareholder protection was made by China between 1995 and

\footnotetext{
${ }^{60}$ World Bank, 'Doing Business: Metholodgy' (2017). Available at: <http://www.doingbusiness.org/methodology>.

${ }^{61}$ World Bank, 'Doing Business 2018' (2017). Available at: 〈http://www.doingbusiness.org>.

${ }^{62}$ Important parameters include the extent of disclosure, director liability, shareholder rights and suits, etc.
} 
2005. ${ }^{63}$ China experienced a jump in its shareholder protection score from 5 to 6.5 . According to this index, although the UK and the US were the top performers in 2005 (with scores of slightly more than 7), China was more protective of shareholders' interests than some developed countries such as Germany and Switzerland. This dataset has since been updated to 2013. ${ }^{64}$ It has been suggested that between 1990 and 2013 China experienced the 'biggest increase in shareholder protection' amongst 30 countries studied. ${ }^{65}$ China, Russia and France were the top performers in shareholder protection in 2013, performing even better than the UK and the US. ${ }^{66}$ To find out the cause of different results, it is necessary to take a closer look at the two studies.

\section{Overview of the Two Indices}

The World Bank's Protecting Minority Investors Index measures the protection of minority investors from conflicts of interest through three major set of indicators. ${ }^{67}$ The goal is to measure the protection of shareholders against directors' misuse of corporate assets for personal gain by distinguishing three dimensions of regulation that address conflicts of interest: i) transparency of related-party transactions (extent of disclosure index ${ }^{68}$ ); ii) shareholders' ability to sue and hold directors liable for self-dealing (extent of director liability index ${ }^{69}$ ); and iii) access to evidence and allocation of legal expenses in shareholder litigation (ease of shareholder suits index ${ }^{70}$ ). Each of the indicators ranges from 0 to 10 , with higher values

\footnotetext{
63 John Armour et al, 'Shareholder Protection and Stock Market Development: An Empirical Test of the Legal Origins Hypothesis' (2009) 6 Journal of Empirical Legal Studies 343.

${ }^{64}$ This is available via Mathias Siems, 'CBR Extended Shareholder Protection Index' (2016). Available at: <https://www.repository.cam.ac.uk/bitstream/handle/1810/256566/cbr-spi-30-countries-codebook-andmethodology.pdf? sequence $=9 \&$ is Allowed $=\mathrm{y}>$.

${ }^{65}$ Katelouzou and Siems (n 6) 133.

${ }^{66}$ Ibid. 134.

${ }^{67}$ World Bank, 'Protecting Minority Investors Methodology' (2018). Available at: <http://www.doingbusiness.org/en/methodology/protecting-minority-investors>.

${ }^{68}$ The extent of disclosure index has five components. For further information on what these five compoenets are and how a score ranging from 1 to 3 is assigned to each of these compenents, see ibid.

${ }^{69}$ The extent of director liability index has seven components. For further information on what these seven compoenets are and how a score ranging from 1 to 2 is assigned to each of these compenents, see ibid.

${ }^{70}$ The ease of shareholder suits index has six components. For further information on what these six compoenets
} 
indicating greater disclosure, greater liability of directors, and greater powers of shareholders to challenge the transaction respectively. The final score is the simple average of the scores for the three set of indicators. The data come from a questionnaire administered to corporate and securities lawyers.

On the other hand, the dataset developed by the Centre for Business Research at the University of Cambridge consists of ten core variables ${ }^{71}$ which act as proxies for shareholder protection law. ${ }^{72}$ The variables were selected using several criteria. ${ }^{73}$ First, they are entitlements which, in theory, may be understood as responses to basic agency problems in business enterprise that might otherwise undermine the value of investors' expected returns. For example, one of the variables, 'feasibility of director's dismissal', reflects the ease with which shareholders can dismiss directors. Secondly, they are entitlements which are considered representative by the researchers of the project. These variables together cover the power of the general meeting and on who decides about its topics; on how voting takes place; on whether directors take the shareholders interests into account; on which legal actions shareholders can file; and on how shareholders are protected in the event of a change of corporate control. Thirdly, the variables selected were ones which were expected to have exhibited a relatively high degree of change over the period studied. The scores are expressed as a value between ' 0 ' and ' 1 '. ' 0 ' would stand for no protection or worst protection offered and ' 1 ' would stand for the best or maximum protection offered with respect to the particular core variable. In other words, the final score that a country will get will be the sum of the scores for all ten variables, meaning a maximum

\footnotetext{
are and how a score ranging from 1 to 2 is assigned to each of these compenents, see ibid.

${ }^{71}$ These ten core variables are: 1) powers of the general meeting for de facto changes; 2) agenda setting power;

3 ) anticipation of shareholder decision facilitated; 4) prohibition of multiple voting rights (super voting rights);

5) independent board members; 6) feasibility of director's dismissal; 7) private enforcement of directors duties (derivative suit); 8) shareholder action against resolutions of the general meeting; 9) mandatory bid; and 10) disclosure of major share ownership.

${ }^{72}$ Siems (n 64).

${ }^{73}$ Armour et al (n 63) 353-356.
} 
final score of ten. The data were not based on questionnaires or surveys of lawyers, as is the case above with the World Bank's index. ${ }^{74}$ The data on legal systems were collated with the assistance of chosen individuals, reviewed and finalised by the main researchers of the project.

\section{Comparing and Digging into the Methodology of the Two Indices}

The apparent divergence of what the two indices suggest can perhaps be explained by their differences in the choice of variables. Although both seek to reveal the cross-country differences in shareholder protection, they may have different objectives and scope, thereby research design, leading to China's different performance in the two indices.

One foremost issue is the timing of the research done. In Armour and colleagues' study, the law in China was last coded in May 2013. Bearing in mind that the most recent company law in China came into effect on 1 March 2014, their research would only reflect the state of the previous company law, as well as other rules and regulations as of May $2013 .{ }^{75}$ In contrast, a new Doing Business Report is issued every year by the World Bank. As of today, the most recent one is 'Doing Business 2018', reflecting the law as of 1 June 2017. Therefore, to compare Armour and colleagues' findings with those of the World Bank, it is more appropriate to refer to 'Doing Business 2014', reflecting the law as of 1 June $2013 .^{76}$ Both indices would then describe the law of China as of roughly the same point of time. In the 2014 report, China was ranked 98th with a score of 5.0 (note a drop in both rank and score in the 2018 report, as aforementioned, when compared to this). By comparison, OECD high income countries on

\footnotetext{
74 Ibid. 351.

${ }^{75}$ But note, as least in a company law context, the differences between China's Company Law 2005 and Company Law 2013 in light of shareholder protection are minimal, as shown in Table 1 above. But the same may not be said for other rules and regulations without some more careful examinations.

${ }^{76}$ The 2014 report data cover regulations measured from June 2012 through May 2013. World Bank, 'Doing Business 2014' (2013). Available at: <http://www.doingbusiness.org/reports/global-reports/doing-business2014>.
} 
average got a score of 6.2 at that time.

Second, the scope of the two studies looks somewhat different. In Armour and colleagues' study, they concerned shareholder protection in listed companies only. ${ }^{77}$ A typical regulatory system of capital market entails three tiers of regulation. ${ }^{78}$ Company law represents the bottom tier of regulation as it applies to all companies, both public and private companies. Securities law represents the second tier of regulation, in that it is only relevant to companies which issue securities to the public. Listing rules represent the top tier of regulation and are relevant only to a relatively small group of companies whose securities are admitted to listing. So, there is a need to consider all these three tiers of regulation for a listed company. By contrast, the Doing Business project overall, launched in 2002 , has the aim of looking at 'domestic small and medium-sized companies and measures the regulations applying to them through their life cycle' ${ }^{79}$ Yet, the basic assumption in compiling the Protecting Minority Investors indicator is, the rules and regulations applicable to 'a publicly traded corporation listed on the economy's most important stock exchange' are taken into account ${ }^{80}$ For example, when they looked at New Zealand, a wide array of rules and regulations were taken into account, such as 'the Companies Act, Financial Reporting Act, Securities Market Act, Exchange Listing Rules, Evidence Act, Limitation Act, Judicature Act, High Court Rules and Rules of Professional Conduct for Barristers and Solicitors' ${ }^{81}$ By contrast, in this regard, the scope of Armour and colleagues' study was somewhat different, when the major point of reference is the company law and 'in some cases' securities law, as well as various codes, listing rules and caselaw. Also, another notable difference is by having constructed longitudinal indices using the time series

\footnotetext{
${ }^{77}$ Siems (n 64) 3.

${ }^{78}$ Iain MacNeil and Alex Lau, 'International Corporate Regulation: Listing Rules and Overseas Companies' (2001) 50 International and Comparative Law Quarterly 787.

${ }^{79}$ World Bank, 'Doing Business: About Us' (2017). Available at: <http://www.doingbusiness.org/about-us>.

${ }^{80}$ World Bank (n 67)

${ }^{81}$ World Bank (n 76) 97
} 
data, Armour and colleagues' study managed to go further to address the issue of the direction of causation between legal and economic change through relevant econometric and statistical techniques. ${ }^{82}$ By contrast, the Doing Business project just seeks to measure and compare business regulations between economies, though time series data are still generated to show year-to-year legal changes.

Third, the scale, resources and staffing of the two projects are different. The Doing Business project was founded by Simeon Djankov, Michael Klein and Caralee McLiesh, under the World Bank. In the 2014 report, data collection and analysis were conducted through under the leadership of Augusto Lopez-Claros with the support of several dozen World Bank employees. In particular for the Protection of Minority Investors index, the data come from a questionnaire administered to corporate and securities lawyers and are based on securities regulations, company laws, civil procedure codes and court rules of evidence. ${ }^{83}$ In 2017 (the information for 2014 is no longer available), the opinions of 12 Chinese lawyers were consulted for the exercise. On the other hand, Armour and colleagues' study was part of a project entitled 'Law, Finance \& Development', led by Simon Deakin, John Armour and Ajit Singh and hosted by the Centre for Business Research at Cambridge, with the support of 10 other researchers, and funding from the Economic and Social Research Council of the UK and other bodies. In particular for the coding of Chinese law, it was predominantly done by Mathias Siems with the input of Rui Wang. ${ }^{84}$ Although there is no ground to question the expertise of Siems and Wang, the World Bank has managed to draw on the opinions of more local lawyers to confirm the laws in each particular economy.

\footnotetext{
${ }^{82}$ Simon Deakin et al, 'Law, Finance and Development: Full Research Report' (2009) ESRC End of Award Report, RES-156-25-0037. Available at: <http://www.researchcatalogue.esrc.ac.uk/grants/RES-156-25$0037 / \mathrm{read}>$.

${ }^{83}$ World Bank (n 67).

${ }^{84}$ Siems (n 64) 28.
} 
Fourth, differences are seen in the choice of variables. As mentioned before, the use of six variables in La Porta and colleagues' initial research was regarded by commentators as 'limited' ${ }^{85}$ The World Bank Index assesses the strength of minority shareholder protections against directors' misuse of corporate assets for personal gain. The research design assumes a related-party transaction between two companies where one individual is the controlling shareholder and a member of the boards of directors of both. The transaction is overpriced and causes damages to the buying company. The Index measures three aspects of investor protections: approval and transparency of related-party transactions (extent of disclosure), liability of company directors for self-dealing (extent of director liability) and shareholders' ability to obtain corporate documents before and during derivative or direct shareholder litigation (ease of shareholder suits). There are 18 variables spreading quite evenly under these three broad areas of concern. By contrast, there are 10 variables in Armour and colleagues' study reflecting five areas of concern, namely, shareholder decision rights, control on directors, shareholder suits, takeover and disclosure of majority stakes. There are notable differences and overlap between these variables. One major difference is the fact that takeover is not an area covered and considered by the World Bank's index. In relation to overlap, one example is the fact that the extent of disclosure variables in the World Bank's index are somewhat connected to the variables on shareholder decision rights in Armour and colleagues' study. The former asks which entities can provide legally sufficient approval for related-party transactions. Meanwhile, the latter concerns more on the shareholders control in substantial property transactions (when the transactions involve half or more of the company's assets). Likewise, the extent of director liability variables (note the ease of shareholder suits variables indeed concern the civil procedure rules which are not examined by Armour and colleagues' study) in

\footnotetext{
${ }^{85}$ The six variables are one share-one vote; proxy by mail; requirement to deposit shares prior to general shareholders meeting; cumulative voting; oppression remedy; and pre-emptive rights.
} 
the World Bank's index may be viewed together with the shareholder suits variables in Armour and colleagues' study. Both consider the availability of derivative suits.

Finally, in light of the critiques on La Porta and colleagues' initial research, subsequent studies have devoted considerable efforts in addressing the former's shortcomings. As said, one innovation, common to all subsequent studies, is the expansion of the number of variables. Another innovation is, Armour and colleagues have used graduated variables, in order to capture more of the detail of legal variation when La Porta and colleagues had largely relied on binary variables. ${ }^{86}$ Furthermore, Armour and colleagues have tried to recognise the methodological constraint imposed on the coding of law, which involves an unavoidable degree of judgement. Therefore, they have made notable efforts in documenting the precise source of legal authority upon which the coding was based, and the grounds of any interpretive judgement exercised. ${ }^{87}$ Similar efforts have been made in the World Bank project. Rather than using 1 and 0 to denote whether a rule is present or not, intermediate result is permitted. ${ }^{88}$ Also, the justification of why a specific score is given to each variable is explained in the report, though the exact legal authority is not pinpointed like Armour and colleagues' study.

\section{Decoding the Results}

It has been shown that China performed well in Armour and colleagues' study but less so in the World Bank's Doing Business project. It is necessary to examine the scores in the selected variables to reveal the reason for discrepancy. In the 2014 Doing Business Report, New Zealand

\footnotetext{
${ }^{86}$ Deakin et al (n 82).

${ }^{87}$ Ibid. See also Siems (n 64).

${ }^{88}$ For example, in the World Bank Index, on which corporate body can provide legally sufficient approval for the related party transaction. A score of 0 is assigned if it is the CEO or the managing director alone; 1 if the board of directors, the supervisory board or shareholders must vote and the interested director/shareholder is permitted to vote; 2 if the board of directors or the supervisory board must vote and the interested director/shareholder is not permitted to vote; 3 if shareholders must vote and the interested director/shareholder is not permitted to vote.
} 
provided the strongest minority investor protections according to the index. The jurisdiction had achieved this excellent result for the ninth year in a row before that. As a side note, it is worth highlighting that the current champion in 2017 was Kazakhstan, a jurisdiction probably least expected by many, when New Zealand slipped into the second. ${ }^{89}$ However, this article does not wish to use either as the source of 'control variables' to compare the two studies when New Zealand and Kazakhstan were not included in Armour and colleagues' study. Instead, this article will compare the scores of the US and UK, which both have the largest financial markets in the world and traditionally perceived as having strong company and financial laws ${ }^{90}$, and China in the 2014 Doing Business Report in order to reveal the possible cause of discrepancies (see Table 2 below). A similar comparison will also be performed later by using the data in Armour and colleagues' study.

Table 2 - Selected Results of Protecting Minority Investors Indicator by the World Bank

\begin{tabular}{|l|c|c|c|}
\hline Indicator & China's & UK's Score & US's Score \\
\hline Extent of disclosure index (0-10) & 10 & 10 & 7 \\
\hline $\begin{array}{l}\text { Which corporate body provides legally } \\
\text { sufficient approval for the transaction }\end{array}$ & 3 & 3 & 1 \\
\hline $\begin{array}{l}\text { Whether disclosure by the interested majority } \\
\text { shareholder-director to the board of directors is }\end{array}$ & 2 & 2 & 2 \\
required & & & \\
\hline
\end{tabular}

\footnotetext{
${ }^{89}$ World Bank (n 61). Kazakhstan has been exceptionally committed to improving its corporate and financial regime. See Horace Yeung et al, 'Institutional Development and the Astana International Financial Centre' (2019) forthcoming in Central Asian Yearbook of International and Comparative Law.

${ }^{90}$ For example, Hansmann and Kraakman once predicted that all jurisdictions would prompt along the US and the UK line in terms of shareholder protection owing to their perceived superiority. Henry Hansmann and Reinier Kraakman, 'The End of History for Corporate Law' (2001) 89 Georgetown Law Journal 439. A 2012 reflection of their arguments can be found in Henry Hansmann and Reinier Kraakman, 'Reflections on the End of History for Corporate Law' in Abdul Rasheed and Toru Yoshikawa (eds), The Convergence of Corporate Governance (Palgrave, 2012).
} 


\begin{tabular}{|c|c|c|c|}
\hline $\begin{array}{l}\text { Whether immediate disclosure of the } \\
\text { transaction to the public, or the shareholders is } \\
\text { required. }\end{array}$ & 2 & 2 & 2 \\
\hline $\begin{array}{l}\text { Whether disclosure in the annual report is } \\
\text { required }\end{array}$ & 2 & 2 & 2 \\
\hline $\begin{array}{l}\text { Whether it is required that an external body, for } \\
\text { example, an external auditor, review the } \\
\text { transaction before it takes place }\end{array}$ & 1 & 1 & 0 \\
\hline Extent of director liability index (0-10) & 1 & 7 & 9 \\
\hline $\begin{array}{l}\text { Whether shareholder plaintiffs are able to sue } \\
\text { directly or derivatively for the damage the } \\
\text { transaction causes to the company }\end{array}$ & 1 & 1 & 1 \\
\hline $\begin{array}{l}\text { Whether a shareholder plaintiff is able to hold } \\
\text { the interested majority shareholder-director } \\
\text { liable for the damage the Buyer-Seller } \\
\text { transaction causes to the company. }\end{array}$ & 0 & 2 & 2 \\
\hline $\begin{array}{l}\text { Whether a shareholder plaintiff is able to hold } \\
\text { the approving body liable for the damage the } \\
\text { transaction causes to the company }\end{array}$ & 0 & 1 & 2 \\
\hline $\begin{array}{l}\text { Whether a court can void the transaction upon } \\
\text { a successful claim by a shareholder plaintiff }\end{array}$ & 0 & 1 & 2 \\
\hline $\begin{array}{l}\text { Whether the interested majority shareholder- } \\
\text { director pays damages for the harm caused to } \\
\text { the company upon a successful claim by the } \\
\text { shareholder plaintiff }\end{array}$ & 0 & 1 & 1 \\
\hline
\end{tabular}




\begin{tabular}{|c|c|c|c|}
\hline $\begin{array}{l}\text { Whether the interested majority shareholder- } \\
\text { director repays profits made from the } \\
\text { transaction upon a successful claim by the } \\
\text { shareholder plaintiff }\end{array}$ & 0 & 1 & 1 \\
\hline $\begin{array}{l}\text { Whether fines and imprisonment can be applied } \\
\text { against the interested majority shareholder- } \\
\text { director }\end{array}$ & 0 & 0 & 0 \\
\hline Ease of shareholder suits index (0-10) & 4 & 7 & 9 \\
\hline $\begin{array}{l}\text { Whether shareholders owning } 10 \% \text { of the } \\
\text { company's share capital have the right to } \\
\text { inspect the transaction documents before filing } \\
\text { suit }\end{array}$ & 1 & 0 & 1 \\
\hline $\begin{array}{l}\text { Whether shareholders owning } 10 \% \text { of the } \\
\text { company's share capital can request that an } \\
\text { inspector investigate the transaction }\end{array}$ & 0 & 1 & 0 \\
\hline $\begin{array}{l}\text { Whether the plaintiff can obtain any documents } \\
\text { from the defendant and witnesses during trial. }\end{array}$ & 0 & 2 & 4 \\
\hline $\begin{array}{l}\text { Whether the plaintiff can obtain categories of } \\
\text { relevant documents from the defendant without } \\
\text { identifying each document specifically }\end{array}$ & 0 & 1 & 1 \\
\hline $\begin{array}{l}\text { Whether the plaintiff can directly examine the } \\
\text { defendant and witnesses during trial }\end{array}$ & 2 & 2 & 2 \\
\hline $\begin{array}{l}\text { Whether the standard of proof for civil suits is } \\
\text { lower than that for a criminal case }\end{array}$ & 1 & 1 & 1 \\
\hline Strength of investor protection index (0-10) & 5.0 & 8.0 & 8.3 \\
\hline
\end{tabular}


Source: World Bank, 'Doing Business 2014' (2013).

It can be seen that China and the UK were highly regarded in the extent of disclosure required from companies (less so for the US). Both scored a perfect 10 in this area. Comparatively, China fared less well against the US and UK in the ease of shareholder suits, and even far worse, in the extent of director liability. Information is important for both investor and shareholder protection. IPO prospectuses allow prospective shareholders to make informed investment decisions. Meanwhile, existing shareholders' participation in the decision-making process requires their access to information, mainly disseminated via regular financial reports and ad hoc announcements. Furthermore, the early Chinese Company Law gave shareholders the right to review and examine some of the company documents. ${ }^{91}$ At the basic level, this generally meant that shareholders could, usually upon payment of a fee, obtain documents and information including a copy of the company articles, personal information of company officers, financial reports, minutes of shareholders' meetings and so on. On top of these, the 2005 law granted shareholders the power to examine the company's accounts. ${ }^{92}$ This access is particularly crucial because some accounting anomalies might be reflected in the accounting records rather than the financial statements. However, China lost five points in the ease of shareholder suit when the shareholder plaintiff has limited rights in obtaining any documents from the defendant in a shareholder suit, when for example compared to the US. Such rights are not normally determined by the company and financial law, but rather the civil procedural rules of a jurisdiction. In this context of China, the competent legislation is the Civil Procedure Law. $^{93}$

Turning to the extent of director liability, where China performed rather poorly, one notable

\footnotetext{
${ }^{91}$ Company Law 1993, arts 32 \& 110.

92 Company Law 2005, art 33.

93 The law was adopted at the 4th Session of the Seventh National People's Congress on April 9, 1991; amended for the first time on October 28, 2007; and amended for the second time on August 31, 2012.
} 
shortfall in China's regime was the absence of an unfair prejudice remedy which effectively gave the US and the UK substantial points in the index. Under Section 994 of the UK Companies Act, a shareholder, who believes he or she has been unfairly discriminated against or unfairly prejudiced by the manner in which the affairs of his or her company have been conducted, may seek assistance from the court. In the view of Kershaw, non-arm's length related-party transactions constitutes 'a visible departure from fair dealing' and can therefore be regarded as "unfair prejudice"" ${ }^{94}$ There is a wide range of remedies at the court's disposal if the action succeeds, including but not limited to, requiring the company or any other person to acquire the shareholder's shares to give the latter an exit right; or requiring the company or any other person to pay compensation to a person; or setting aside action taken by the company or the board in breach of the law; etc. ${ }^{95}$ On the face of it, in China, if a shareholder of the company abuses its shareholder's rights, thereby causing losses to the company or other shareholders, the wrongdoing shareholder shall be liable for compensation according to the law. ${ }^{96}$ Hawes and colleagues regard this as the Chinese 'unfair prejudice' remedy. ${ }^{97}$ However, at the same time, they indicate that the wording of the Chinese remedy is vague, and the Supreme People's Court of China has not clarified its meaning. Huang also agrees that this remedy 'is too vague to be capable of being enforced in reality' ${ }^{98}$ To sum up, a less plaintiff friendly Civil Procedure Law and the absence of an unfair prejudice remedy in Chinese company law has certainly cost China dearly in the World Bank ranking.

With respect to Armour and colleagues' study, China, Russia and France were the top

\footnotetext{
${ }^{94}$ David Kershaw, Company Law in Context: Text and Materials (OUP, 2012) 694.

95 UK's Companies Act 2006 s 996.

${ }^{96}$ Company Law 2013, art 20.

${ }^{97}$ Colin Hawes et al, 'The Chinese "Oppression" Remedy: Creative Interpretations of Company Law by Chinese Courts' (2015) 63 American Journal of Comparative Law 559.

${ }^{98}$ Hui Huang, 'Shareholder Derivative Litigation in China: Empirical Findings and Comparative Analysis' (2012) 27 Banking \& Finance Law Review 619, 625.
} 
performers in shareholder protection in 2013, outperforming the US and the UK. It may be useful to see in what way China has done better than the latter two. For a breakdown of scores for these three jurisdictions in Armour and colleagues' index, see Table 3.

Table 3 - Performance of the US, UK and China in Armour and Colleagues' Shareholder

\section{Protection Index in 2013}

\begin{tabular}{|l|l|l|l|l|l|l|l|l|l|l|l|}
\hline Variable $^{*}$ & $\mathbf{1}$ & $\mathbf{2}$ & $\mathbf{3}$ & $\mathbf{4}$ & $\mathbf{5}$ & $\mathbf{6}$ & $\mathbf{7}$ & $\mathbf{8}$ & $\mathbf{9}$ & $\mathbf{1 0}$ & Aggre. \\
& & & & & & & & & & & Score \\
\hline China & 1 & 0.75 & 0.5 & 1 & 0.6 & 0.5 & 0.75 & 1 & 1 & 0.75 & 7.85 \\
\hline UK & 0.75 & 0.5 & 0.5 & 0 & 1 & 0.9 & 0.75 & 1 & 1 & 1 & 7.40 \\
\hline US & 0.75 & 1 & 1 & 0.5 & 1 & 0.75 & 0.5 & 1 & 0 & 0.75 & 7.25 \\
\hline
\end{tabular}

*Note: Variables 1 to 10 are: 1) Powers of the general meeting for de facto changes; 2) Agenda setting power; 3) Anticipation of shareholder decision facilitated; 4) Prohibition of multiple voting rights (super voting rights); 5) Independent board members; 6) Feasibility of director's dismissal; 7) Private enforcement of directors duties (derivative suit); 8) Shareholder action against resolutions of the general meeting; 9) Mandatory bid; and 10) Disclosure of major share ownership.

It can be seen that the aggregate scores of the three jurisdictions were not substantially different. Katelouzou and Siems attributed China's success to the adoption of the Chinese Company Law 2005 which had introduced some Western standards of shareholder protection. ${ }^{99}$ From Table 3 , it can be seen that China has done notably better than the US and the UK in relation to Variables $1 \& 4$. Variable 1 is about the shareholder approval in large asset sales. ${ }^{100}$ Under the Chinese Company Law, if the amount of the major assets purchased or sold or the amount of security provided by a listed company within one year exceeds 30 percent of the total assets of the company, a resolution shall be passed by the general meeting and adopted by two thirds or more of the voting rights held by the shareholders present at the meeting. ${ }^{101}$ By contrast, in the UK, ad hoc disclosures will be required in the case of significant transactions for 'premium'

\footnotetext{
${ }^{99}$ Katelouzou and Siems (n 6).

${ }^{100}$ If the sale of more than 50 percent of the company's assets requires approval of the general meeting, a score 1 is assigned; if the sale of more than 80 percent of the assets requires approval, 0.5 is given; otherwise, 0 is given. If no clearly predominant opinion exists, intermediary score is possible.

${ }^{101}$ Company Law 2005, art 122; Company Law 2013; art 121.
} 
issuers only. ${ }^{102} \mathrm{~A}$ transaction is classified by assessing its size relative to that of the listed company proposing to make it. ${ }^{103}$ The comparison of size is made by using the percentage ratios resulting from applying the class test calculations to a transaction. A Class 2 transaction will be one where any percentage ratio is 5 percent or more but each is less than 25 percent; and Class 1 transaction for a percentage ratio 25 percent or more. Class 2 transaction requires the notification of certain information on the transaction to the market via a 'Regulatory Information Service', one example of which is Regulatory News Service, owned by the London Stock Exchange. For Class 1 transaction, in addition to using Regulatory Information Service, it requires publication of a 'Class 1 Circular', approved by the UK Listing Authority, to its shareholders and obtain their approval in a general meeting for the transaction. ${ }^{104}$ In the US, approval is required in case of 'substantially all of its property and assets', but there is not a specific qualifying percentage. ${ }^{105}$

China has also done notably better in relation to Variable 4 . Variable 4 is essentially about whether the one-share-one-vote principle will apply. ${ }^{106}$ Scholars have divided opinions regarding the one-share-one-vote principle. ${ }^{107}$ On the one hand, it is regarded as a bedrock principle of corporate governance. On the other hand, it may destroy shareholder democracy. In China, the company law firmly recognises the principle. ${ }^{108}$ In the UK, the principle is a default position under the Companies Act 2006, but subject to any provision of the company's articles. ${ }^{109}$ Although the UK has one of the most liberal regimes in this regard (therefore scored 0 point in this variable), Huang observes that multiple voting rights have been rare among UK listed companies owing to the market pressure and successful opposition from institutional investors. ${ }^{110}$ In the US, like the UK, the principle is a default position under Delaware's company law but companies can opt out from it. ${ }^{111}$ The NYSE and NASDAQ permit preexisting shares with multiple voting rights, but once listed, companies are prohibited to

\footnotetext{
${ }^{102}$ For the distinction between premium and standard listings, see Horace Yeung, 'The Admission and Regulation of Overseas Issuers: A Survey of Top Four Financial Centres' in Douglas Cumming and Sofia Johan (eds.), The Oxford Handbook of IPOs (OUP, forthcoming in 2018).

${ }^{103}$ UK Listing Rule (LR) 10.2.1G.

${ }^{104}$ LR 10.5.1R.

105 Delaware General Corporation Law § 271(a).

${ }^{106}$ If there is a prohibition of multiple voting rights, 1 is given; otherwise, 0 is given. Intermediary score is possible.

${ }^{107}$ For a literature review, see Flora Huang, 'Dual Class Shares around the Top Financial Centres' [2017] Journal of Business Law 137, 138-141.

108 Company Law 2005, art 104; Company Law 2013; art 103.

${ }^{109}$ UK Companies Act 2006 s 284.

${ }^{110}$ Huang (n 107) 145

${ }^{111}$ Delaware General Corporation Law $§ 212$ (a)
} 
implement changes that would discriminate against the interests of existing shareholders. ${ }^{112}$

At the same time, there are areas that China has done notably less well. Variable 5 concerns the independent director requirement. ${ }^{113}$ As said before, in China, independent directors are to account for at least one-third of the membership of a company's board of directors. ${ }^{114}$ In the UK, the UK Corporate Governance Code requires that except for smaller companies, at least half the board, excluding the chairman, should comprise independent directors. ${ }^{115}$ The US position has been the same. ${ }^{116}$ Variable 6 concerns the possibility to remove a director. ${ }^{117}$ Under Chinese company law, shareholders may remove a director. ${ }^{118}$ It is unclear why China scored lower than the US and the UK when the justifications apparently relate to whether the reason of removal and compensation would be required. But the former 'seems not to be required under the Company Law 2005' and the latter is understood to be a possibility only. ${ }^{119}$ This certainly points to the problem of using graduated variables and the degree of subjective judgement required in assigning a score to the variables. It is not always clear why a particular score is given.

\section{Reconciling the Results}

On the cover page of Mathias Siems' Comparative $L_{a w}{ }^{120}$, which provides a very accessible and well written account of the research methodology, one can find photos of apples and oranges on the book's cover. In the view of Suk, this reflects the challenge of comparative analysis that it is difficult to "capture fully the unique, distinctive and incomparable features of any given legal problem, culture, institution or case'. ${ }^{121}$ In the context of this paper, comparing the two indices compiled by Armour and colleagues and the World Bank may really be akin to comparing apples and oranges. As discussed before, although the prima facie ambits of the

\footnotetext{
112 NYSE Listed Company Manual r313(A); and NASDAQ r5640.

${ }^{113}$ If at least half of the board members must be independent, a score of 1 is assigned; if 25 percent of them must be independent, 0.5 is given; otherwise, 0 is given. Intermediary score is possible.

${ }^{114}$ Guidelines for Introducing Independent Directors to the Board of Directors of Listed Companies, art I(3).

115 The UK Corporate Governance Code B1.2. Here a smaller company is one that is below the FTSE 350.

116 NYSE Listed Company Manual r303A.01.

${ }^{117}$ A score of 0 is assigned if good reason is required for the dismissal of directors; 0.25 given if directors can always be dismissed but are always compensated for dismissal without good reason; 0.5 given if directors are not always compensated for dismissal without good reason but they could have concluded a non-fixed term contract with the company; 0.75 given if in cases of dismissal without good reason directors are only compensated if compensation is specifically contractually agreed; 1 given if there are no special requirements for dismissal and no compensation has to be paid. Intermediary score is possible.

118 Company Law 2005, art 38; Company Law 2013; art 37; cf. UK Companies Act 2006 s 168 for example.

${ }^{119}$ Siems (n 64) 29.

120 Siems (n 37).

${ }^{121}$ Julie Suk, 'Beyond Apples and Oranges' (2016) 64 American Journal of Comparative Law 512.
} 
indices look the same as written on the tin, one is called 'Shareholder Protection Index' and another one is called the 'Protecting Minority Investors indicator', the actual focuses are somewhat different. The former's concern lies in listed companies whereas that of the latter lies more on small and medium-sized enterprises. These two types of companies face different challenges in corporate governance. In listed companies, there is a higher likelihood of separation of ownership and control. The classic agency problem in this organisational structure lies in assuring that the managers are responsive to the shareholders' interest rather than pursuing their own personal interests. ${ }^{122}$ In small and medium-sized enterprises, where a concentrated ownership structure is more likely, the concern lies more with the conflict between majority and minority shareholders. The majority generally have a tendency to expropriate the minority.

As a result, it makes sense for the World Bank index to place more focus on the unfair prejudice, or also called oppression, remedy, which is useful in a private company (i.e. non-listed) setting. Despite a range of possible outcomes arising from a successful action, the most common one is an order that the petitioners' shares be purchased by the controllers or the company. ${ }^{123} \mathrm{~A}$ share purchase order gives the petitioner an opportunity to exit from the company with the fair value of his or her investment. In a sharp contrast, this might not be useful in a public company where shareholders can choose to sell their shares via the market. That is why the presence of this unfair prejudice remedy has been rightly excluded from their variables in Armour and colleagues' study. Furthermore, it is questionable as to whether in practice the remedy is a powerful shareholder protection weapon. Private enforcement of shareholder rights has never been the main landscape of the English model of corporate governance (but the story of the US has been entirely different, which is far more litigious). ${ }^{124}$ One explanation to this is that both civil procedure rules and substantive corporate law seem more 'plaintiff-friendly' in the US than another side of the Atlantic. ${ }^{125}$ As discussed before, there is a debate of whether the unfair prejudice remedy actually exists in China. ${ }^{126}$

Whilst the difference in the scope of comparison may offer an explanation for China's varying

\footnotetext{
${ }^{122}$ Armour et al (n 50) 29-30.

${ }^{123}$ Paul Davies and Sarah Worthington, Gower Principles of Modern Company Law (Sweet \& Maxwell, 2016) 680.

${ }^{124}$ John Armour et al (n 32).

125 Ibid. 696.

${ }^{126}$ Hawes et al (n 97).
} 
performance in the two indices, in terms of the overlap areas, the two indices in principle do point to consistent observations. As mentioned, powers of the general meeting to control substantial property transactions in China have been viewed positively by Armour and colleagues. On the other hand, both China and the UK have scored full points in the extent of disclosure index of the World Bank which relates to the transparency and approval of relatedparty transactions. Similarly, although China has scored only one point (out of ten) in the extent of director liability of the World Bank index, this one point has already reflected the availability of derivative suits in China, which can largely be confirmed by Variable 7 of Armour and colleagues' study. ${ }^{127}$

\section{Conclusion}

The strength of a jurisdiction in protecting shareholders can be interpreted differently depending on the choice of variables in a leximetric study. In comparing the two indices concerning the state of shareholder protection in China, it can be seen that the breadth of variables with regard to corporate and financial law generally is notable in Armour and colleagues' study, while the depth of variables is notable in the World Bank study highlighting the specific issues in controlling a related-party transaction. Although the performance of China in the two indices is varied, this outcome does not necessarily cast doubt on the robustness of either studies. The discrepancy largely comes from the angles chosen. Armour and colleagues' study concerns more about the principal-agent conflict in a listed company, whilst the World Bank study concerns more about the majority-minority conflict in a small and medium-sized enterprise. Apparently, China has done well in the former through various reforms to its corporate and financial law. Meanwhile, for the latter, the World Bank is right to say, the absence of an explicit oppression remedy and more plaintiff friendly civil procedure rules may be a concern. Needless to say, each study has its own problem. In Armour and colleagues' study, it is not always clear how values are assigned to the graduated variables despite an attempt to be transparent in their coding process. In the World Bank study, if the focus is on small and medium-sized enterprise, it is unclear why securities law and listing rules have to be consulted when it is not normal for them to go to the stock market for money. All in all, the bottom line

\footnotetext{
${ }^{127}$ Under Variable 7, if derivative action is not available or its hurdle is too high (requires at least 20 percent of share capital to bring it), a score 0 is assigned; if there are some restrictions (e.g. certain percentage of share capital), 0.5 is given; if it is readily available, 1 is given. Intermediary score is possible, although it is rather unclear why both China and the UK were assigned the same score of 0.75 when the litigants in China must possess more than 1 percent of shares in the company. See art 151 of the Chinese Company Law 2013. Such a quantitative restriction does not exist in the UK, despite the existence of other procedural hurdles (see UK's Companies Act 2006 ss 260-264).
} 
is both studies are certainly capable of showing some insights in the strengths and weaknesses of the Chinese system, as well as providing a basis for cross-country comparison, but with an important understanding that both studies managed to consider the laws-on-the-books only. Effective law enforcement is a primary concern for any legal systems. While the laws-on-thebooks are easier for researchers to turn them into numerical indices, these rules may have little to do with the reality of actual practice, particularly in developing countries like China. ${ }^{128}$ Even if a country is getting the highest score in a study, it does not necessarily mean that shareholders are actually better protected in that particular country than others.

${ }^{128}$ Coffee (n 32) 244. 